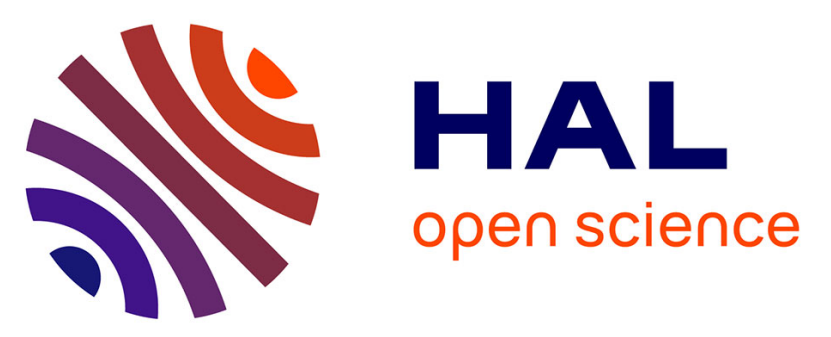

\title{
Beneficial traits of root endophytes and rhizobacteria associated with plants growing in phytomanaged soils with mixed trace metal-polycyclic aromatic hydrocarbon contamination
}

Petra Kidd, Analía Álvarez, Vanessa Álvarez-López, Andrea Cerdeira-Pérez, Beatriz Rodríguez-Garrido, Ángeles Prieto-Fernández, Michel Chalot

\section{To cite this version:}

Petra Kidd, Analía Álvarez, Vanessa Álvarez-López, Andrea Cerdeira-Pérez, Beatriz RodríguezGarrido, et al.. Beneficial traits of root endophytes and rhizobacteria associated with plants growing in phytomanaged soils with mixed trace metal-polycyclic aromatic hydrocarbon contamination. Chemosphere, 2021, 277, pp.130272. 10.1016/j.chemosphere.2021.130272 . hal-03180392

\author{
HAL Id: hal-03180392 \\ https://hal.science/hal-03180392
}

Submitted on 27 Jul 2021

HAL is a multi-disciplinary open access archive for the deposit and dissemination of scientific research documents, whether they are published or not. The documents may come from teaching and research institutions in France or abroad, or from public or private research centers.
L'archive ouverte pluridisciplinaire HAL, est destinée au dépôt et à la diffusion de documents scientifiques de niveau recherche, publiés ou non, émanant des établissements d'enseignement et de recherche français ou étrangers, des laboratoires publics ou privés. 
1 Beneficial traits of root endophytes and rhizobacteria associated with plants growing in phytomanaged soils with mixed trace metal-polycyclic aromatic hydrocarbon contamination

4 Petra S. Kidd ${ }^{\mathrm{a} \dagger}$, Analía Álvarez ${ }^{\mathrm{b}, \mathrm{c} *}$, Vanessa Álvarez-López ${ }^{\mathrm{a}, 1}$, Andrea Cerdeira-Pérez ${ }^{\mathrm{a}}$, Beatriz 5 Rodríguez-Garrido a , Ángeles Prieto-Fernández a , Michel Chalot d,e

$7{ }^{{ }^{a}}$ Instituto de Investigaciones Agrobiológicas de Galicia (IIAG), Consejo Superior de 8 Investigaciones Científicas (CSIC), Avda. de Vigo s/n, Santiago de Compostela 15705, Spain

9 b Planta Piloto de Procesos Industriales Microbiológicos (PROIMI-CONICET), Avenida Belgrano 10 y Pasaje Caseros, Tucumán 4000, Argentina

$11^{\mathrm{c}}$ Facultad de Ciencias Naturales e Instituto Miguel Lillo, Universidad Nacional de Tucumán 12 (UNT), Miguel Lillo 205, Tucumán 4000, Argentina

${ }^{\mathrm{d}}$ UMR CNRS 6249 Chrono-environnement, Université Bourgogne Franche-Comté, 25200

\section{Montbéliard, France}

${ }^{\mathrm{e}}$ Université de Lorraine, Faculté des Sciences et Technologies, 54000 Nancy, France

${ }^{1}$ current address: University of Santiago de Compostela, Department of Crop Production (USC),

17 Spain

$\dagger$ Deceased

*Corresponding author:

Analía Álvarez. Avenida Belgrano y Pasaje Caseros, Tucumán 4000, Argentina. Tel: +54-381- 
ABSTRACT

The diversity of cultivable bacteria associated with plants from phytomanaged soils with mixed trace metal (TM) and polycyclic aromatic hydrocarbon (PAH) contamination in Pierrelaye (France) was evaluated. The emphasis was on the cultivable bacterial community since the overall objective is to obtain bioinoculants to improve the remediation of this type of contaminated site. Root endophytic and rhizosphere soil bacterial counts were determined, and isolates were pooled by amplified rDNA restriction analysis and identified by $16 \mathrm{~S}$ rDNA sequencing. Isolates were further characterised for the production of plant growth-promoting (PGP) substances, and resistance to TM. The selected strains were evaluated for their ability to degrade PAHs. The potential of cell-free microbial supernatant to increase the mobilisation of PAHs from the polluted soil of Pierrelaye was also evaluated. Proteobacteria and Actinobacteria dominated the collection of isolates, and differences in taxonomic diversity were observed between plant species (Populus or Zea mays) and depending on the remediation treatment (Populus inoculation with mycorrhizae or Populus intercropping with Alnus). The majority of isolates exhibited at least one of the tested PGP traits, as well as resistance to more than one TM. Several rhizosphere, endophyte and even one bulk soil isolate showed high rates of fluoranthene and pyrene dissipation. The endophyte their potential in rhizoremediation processes. molecules capable of improving the availability of PAHs from the soil of Pierrelaye. A selection of the most interesting strains was made for other re-inoculation experiments in order to assess 
50 Keywords: organic pollutants; phytomanagement; plant-growth promoting bacteria; Populus;

51 polycyclic aromatic hydrocarbon; trace metals

52

53

54

55

56

57

58

59

60

61

62

63

64

65

66

67

68

69

70

71

72

73

74 


\section{Introduction}

Phytomanaging contaminated soils can successfully restore biological fertility and diversity. Phytomanagement of metal-contaminated sites has increasingly been combined with short rotation coppicing (SRC) for the production of bioenergy (Chalot et al., 2020; Mench et al., 2009; Vangronsveld et al., 2009; Ziegler et al., 2019) or fiber-based material (Jeannin et al., 2020). SRC consists of densely planted high yielding poplar and willow species that can be harvested every 25 years to produce woody biomass. Willow and poplar species are recognised for their tolerance to metals and, in some species or cultivars, for their potential to extract trace metals (TM) such as Cd and $\mathrm{Zn}$ from contaminated soils (Chalot et al., 2020; Kidd et al., 2015). The use of polyclonal stands of Salix and Populus clones rather than monocultures has also been recommended in the phytomanagement of contaminated soils using SRC. They can offer several benefits in terms of plant productivity and nutrition, soil quality and biodiversity, and pest control (Kidd et al., 2015; Mench et al., 2010). Alder is an important pioneer species of degraded and metal-contaminated soils, and intercropping this woody plant with Populus or Salix has been proposed as a means of enhancing phytoremediation efficiency (Kidd et al., 2015).

Plants have been shown to promote the abundance of beneficial microorganisms in their environment, and in particular in the endosphere and rhizosphere (Thijs et al., 2017). These mutualistic plant-microbial symbioses can dramatically improve soil phytoremediation processes by promoting plant health and growth and by modifying the mobility and availability of contaminants (Mendes et al., 2013). Plant growth-promoting bacteria (PGPB) can improve plant nutrition by increasing the availability of essential plant nutrients, such as nitrogen $\left(\mathrm{N}_{2}\right.$-fixing organisms), phosphorus (by solubilisation or mineralization through the production of organic acids and/or phosphatases) or iron (by releasing siderophores). They can also directly influence 
plant growth and physiology through the production of phyto-hormones [e.g. indoleacetic acid (IAA)].

The application of plant-associated bacterial inoculants is gaining increasing interest in sites of mixed contamination, caused by the presence of organic and inorganic compounds. Polycyclic aromatic hydrocarbons (PAHs) are some of the most widespread organic pollutants; their fate in soils is of great environmental concern due to their potential toxicity, mutagenicity and carcinogenicity (Baoune et al., 2019). Mixed contaminated soils represent a source of potentially beneficial bacteria associated with plants that could be used as part of microbial-assisted remediation strategies targeting this type of site (Weyens et al., 2009). Selection of PAH degraders with metal tolerance and surfactant production abilities, or combining PAH degraders with biosurfactant producers, is of particular interest since surfactants enhance the contaminant solubility (Hickey et al., 2007). Endophytic bacteria can be a great option as bioinoculants because they have the advantage of proliferating in plant tissue, thus facing less competition for nutrients and being protected from the high stress environments of polluted soils (Pawlik et al., 2020). However, few studies have identified PAH-degrading or biosurfactant-producing endophytes.

The objectives of this study were to: (a) assess the cultivable bacterial diversity associated with plants under different phytomanagement options based on poplar SRC established in a contaminated mixed site in Pierrelaye (France), (b) isolate root endophytes and rhizobacteria associated with plants, (c) characterize the bacterial strains for traits promoting plant growth, (d) analyse bacterial strains for PAH degradation capacity, biosurfactant production potential and TM tolerance, and (e) assess the influence of certain biosurfactant producers on the availability of PAHs. The general hypothesis is that certain cultivable bacteria isolated from contaminated sites can produce bioinoculants which can greatly improve the remediation of PAH-contaminated soils.

\section{Materials and methods}




\subsection{Soil and plant material}

Soil and plant samples were collected from the experimental field site of Pierrelaye (northwest of Paris, France). Long-term (>100 years) irrigation of these agricultural soils with wastewater from Paris resulted in a mixed contamination of both $\mathrm{TM}$ (mostly $\mathrm{Zn}, \mathrm{Cd}, \mathrm{Pb}$ and $\mathrm{Cu}$ ) and organic pollutants (including PAHs). A description of the general soil properties on this site is given by Ciadamidaro et al. (2017), while data of TM concentration in soil were published by Lamy et al. (2006) and Pottier et al. (2015). Two phytomanagement field trials were established on the Pierrelaye site, one in 2007 (project PHYTOPOP) based on the SRC using 14 different poplar cultivars (Foulon et al., 2016a, 2016b; Pottier et al., 2015), the second in 2011 (project BIOFILTREE) to assess the effect of mycorrhizal inoculation by intercropping Populus with Alnus glutinosa (Ciadamidaro et al., 2017).

The present work is based on rhizosphere soil, plant samples and bulk soil collected from plots with the clone Populus trichocarpa $\times$ Populus maximowiczii Skado [non-inoculated (NI) or inoculated (INOC) with mycorrhizal fungi], from plots with the non-inoculated poplar Skado intercropped with Alnus (referred to as intercropped Populus plots in the whole manuscript), from plots adjacent to the BIOFILTREE trial planted with maize and from non-planted soil (bulk soil) from the BIOFILTREE field trial. In addition, the rhizosphere soils from Populus and bulk soil from the PRHYTOPOP field trial located also in Pierrelaye were studied. Sampling of soils and plant roots was carried out according to Foulon et al. (2016a, 2016b). Five replicate of each sample were studied. 
Five grams of bulk soil or fresh rhizosphere soil of five Populus and maize plants were suspended in $45 \mathrm{~mL}$ sterile sodium hexametaphosphate solution (1\%) and shaken for $30 \mathrm{~min}$ in an end-overend shaker. Soil suspensions were diluted in 10-fold series and plated in duplicate onto 284 agar medium (Schlegel et al., 1991) supplemented with $100 \mu \mathrm{g} / \mathrm{mL}$ of cycloheximide. The 284 medium contains (g/L): 6.06 Tris- $\mathrm{HCl}, 4.68 \mathrm{NaCl}, 1.49 \mathrm{KCl}, 1.07 \mathrm{NH}_{4} \mathrm{Cl}, 0.43 \mathrm{Na}_{2} \mathrm{SO}_{4}, 0.2 \mathrm{MgCl}_{2} .6 \mathrm{H}_{2} \mathrm{O}$, $0.03 \mathrm{CaCl}_{2} .2 \mathrm{H}_{2} \mathrm{O}, 0.04 \mathrm{Na}_{2} \mathrm{HPO}_{4} \cdot 2 \mathrm{H}_{2} \mathrm{O}, 10 \mathrm{~mL} \mathrm{Fe}(\mathrm{III}) \mathrm{NH}_{4}$ citrate solution (containing 48 $\mathrm{mg} / 100 \mathrm{~mL}$ ) plus oligoelements $\left(1.5 \mathrm{mg} \mathrm{FeSO}{ }_{4} .7 \mathrm{H}_{2} \mathrm{O}, 0.3 \mathrm{mg} \mathrm{H}_{3} \mathrm{BO}_{4}, 0.19 \mathrm{mg} \mathrm{CoCl}_{2} . \mathrm{H}_{2} \mathrm{O}, 0.1 \mathrm{mg}\right.$ $\left.\mathrm{MnCl}_{2} .4 \mathrm{H}_{2} \mathrm{O}, 0.08 \mathrm{mg} \mathrm{ZnSO} 4.7 \mathrm{H}_{2} \mathrm{O}, 0.02 \mathrm{mg} \mathrm{CuSO} 4.5 \mathrm{H}_{2} \mathrm{O}, 0.036 \mathrm{mg} \mathrm{Na} 2 \mathrm{MoO}_{4} .2 \mathrm{H}_{2} \mathrm{O}\right)$ adjusted to $\mathrm{pH}$ 7. The medium was supplemented with a mixture of different carbon sources $(\mathrm{g} / \mathrm{L}): 0.7$ lactate, 0.5 glucose, 0.7 gluconate, 0.5 fructose, and 0.8 succinate. After seven days of incubation at $28{ }^{\circ} \mathrm{C}$, colony forming units (CFUs) were counted and calculated per gram dry weight (DW) soil. Distinct colony morphotypes associated with each sample group were sub-cultured at least three times to ensure purity and cryopreserved.

To isolate the root endophytic bacteria of NI Populus, root samples (0.2-0.3 g) were surfacesterilised for $10 \mathrm{~min}$ in $2 \% \mathrm{NaClO}$ solution supplemented with one droplet Tween 80 per $100 \mathrm{ml}$ solution, and were subsequently rinsed three times for $1 \mathrm{~min}$ in sterile deionised water. For maize, root samples $(0.2-0.3 \mathrm{~g})$ were surface-sterilised by sequential immersion in $5 \% \mathrm{NaClO}$ solution supplemented with one droplet Tween 80 per $100 \mathrm{ml}$ solution for $10 \mathrm{~min}$ and in $75 \%(\mathrm{v} / \mathrm{v})$ ethanol for $1 \mathrm{~min}$. The surface-sterilisation process was checked by plating aliquots of the third rinsing solution on 869 medium [(g/L): 1.0 tryptone, 0.5 yeast extract, $0.5 \mathrm{NaCl}, 0.1$ glucose, and 0.035 $\mathrm{CaCl}_{2} \cdot 2 \mathrm{H}_{2} \mathrm{O}$ ]. No growth on these control plates after seven days indicated successful sterilisation. The concentrations of $\mathrm{NaClO}$ and the sterilisation times were empirically determined in previous studies. After surface sterilisation, the root tissue was macerated in $10 \mathrm{~mL}$ of $10 \mathrm{mM} \mathrm{MgSO}_{4}$ using a Polytron PT1200E homogeniser (Kinematica AG). Ten-fold serial dilutions were plated in duplicate on 1/10 strength 869 agar medium, CFUs were determined as above and calculated per 
gram fresh root weight. Distinct colony morphotypes were sub-cultured at least three times to ensure purity and cryopreserved.

\subsection{Phenotypic characterisation of bacterial isolates}

The tolerance to TM was tested growing the strains at $28^{\circ} \mathrm{C}$ for seven days in 284 agar medium (see above) supplemented with $\mathrm{Cd}, 0.1 \mathrm{mM} ; \mathrm{Cu}, 1.0 \mathrm{mM} ; \mathrm{Pb}, 1.0 \mathrm{mM}$ or $\mathrm{Zn} 2.5 \mathrm{mM}$. The ability to solubilize inorganic phosphate was assessed in NBRIP agar medium adjusted to $\mathrm{pH} 7.0$, modified from Nautiyal (1999) supplied with $5 \mathrm{~g} / \mathrm{L}$ of hydroxyapatite and incubated at $28{ }^{\circ} \mathrm{C}$ for 5 days. Yeast extract was added since some strains were unable to grow in yeast-free NBRIP medium. Siderophore production was detected in a modified 284 liquid medium (without Fe) using the Chrome Azurol S (CAS) method described by Schwyn and Neilands (1987). The ability of isolated strains to produce IAA was evaluated in liquid medium, modified from Sheng et al. (2008) supplemented with $0.5 \mathrm{mg} / \mathrm{mL}$ of tryptophan. After five days of incubation at $28{ }^{\circ} \mathrm{C}$, cultures were centrifuged and the presence of IAA was evaluated spectrophotometrically (535 nm) after incubating the supernatant with Salkowski reagent for $25 \mathrm{~min}$. Strains were screened for potential biosurfactant production using the qualitative method of Chen et al. (2007).

\subsection{Genotypic characterisation of bacterial isolates}

For DNA extraction, purified strains were grown in 1/10 strength 869 liquid medium; and genomic DNA was extracted from bacterial cell pellets according to Mergeay et al. (1985). Polymerase chain reaction (PCR) amplification of 16S rRNA genes was carried out in mixtures containing 100 ng/ $\mu$ l DNA, 1× High Fidelity PCR buffer (Invitrogen, Carlsbad, CA, USA), 0.2 $\mathrm{mM}$ of each of the four deoxynucleoside triphosphates, $2 \mathrm{mM} \mathrm{MgCl} 2,0.2 \mu \mathrm{M}$ each of the forward 
and reverse primers, and $1 \mathrm{U}$ of High Fidelity Platinum Taq DNA polymerase (Invitrogen, Carlsbad, CA, USA) per $50 \mu \mathrm{l}$. The universal 1392R (5'-ACGGGCGGTGTGTRC-3') and the bacteria-specific 26F (5'-AGAGTTTGATCCTGGCTCAG-3') primers were used for prokaryotic 16S rRNA gene amplification. Cycling conditions consisted of: one denaturation cycle at $94{ }^{\circ} \mathrm{C}$ for $5 \mathrm{~min}$, followed by 30 cycles at $94{ }^{\circ} \mathrm{C}$ for $1 \mathrm{~min}, 45{ }^{\circ} \mathrm{C}$ for $45 \mathrm{~s}$, and $72{ }^{\circ} \mathrm{C}$ for $1.5 \mathrm{~min}$, and completed with an extension cycle of $10 \mathrm{~min}$ at $72{ }^{\circ} \mathrm{C}$. PCR products were purified using the QIAquick PCR purification columns (Qiagen, Valencia, CA, USA) and quantified spectrophotometrically, using the Nanodrop spectrophotometer (ND-1000, Isogen Life Science). The PCR products were subjected to $16 \mathrm{~S}$ rDNA restriction analysis (ARDRA), used for screening the collection of isolates.

For ARDRA, aliquots of the PCR products were digested overnight at $37{ }^{\circ} \mathrm{C}$ with $1 \mathrm{U}$ of the four-base-specific restriction endonuclease $\mathrm{HpyCH} 4$ IV in $1 \times \mathrm{NEB}$ buffer 1 (New England Biolabs, Beverly, MA, USA). The digestion products obtained were separated by electrophoresis in a $1.5 \%$ agarose gel, and visualized by red safe staining and UV illumination. Bacterial strains with the same ARDRA patterns were grouped using the Pearson correlation coefficient and UPGMA clustering algorithm of the Gel Compar Bionumerics programme (Bionumerics Version 5.1, Applied Maths, Belgium). One representative strain of each group was selected for sequencing. Sequence data were checked using the Chromas v.1.45 software (Technelysium Pty. Ltd., Australia) and assessed for similarity with sequences of the Ribosomal Database Project (Cole et al., 2009).

\subsection{PAH degradation capacity}

Based on their plant growth promoting characteristics, a selected number of isolates were cultivated in minimal salt medium (MSM) with a mixture of phenanthrene and fluoranthene and 
pyrene (Sigma-Aldrich). The PAHs were chosen on the basis of the Pierrelaye soil analyses (Supplementary Table 1). The composition of the MSM was as follows: $100 \mathrm{~mL}$ phosphate buffer $\left[\mathrm{Na}_{2} \mathrm{HPO}_{4} \cdot 12 . \mathrm{H}_{2} \mathrm{O}(140 \mathrm{~g} / \mathrm{L}), \mathrm{KH}_{2} \mathrm{PO}_{4}(20 \mathrm{~g} / \mathrm{L})\right], 10 \mathrm{~mL}$ salt solution $\left[\left(\mathrm{NH}_{4}\right)^{2} \mathrm{SO}_{4}(100 \mathrm{~g} / \mathrm{L})\right.$, $\left.\mathrm{MgSO}_{4} \cdot 7 \mathrm{H}_{2} \mathrm{O}(20 \mathrm{~g} / \mathrm{L})\right], 1 \mathrm{~mL} \mathrm{Ca}\left(\mathrm{NO}_{3}\right)^{2} \cdot 3 \mathrm{H}_{2} \mathrm{O}(4.62 \mathrm{~g} / \mathrm{L}), 28 \mathrm{~mL} \mathrm{FeNH}_{4}$ enriched with $18 \% \mathrm{Fe}$ $(48 \mathrm{mg} / 100 \mathrm{~mL}), 1 \mathrm{~mL}$ oligoelements solution ( $1 \mathrm{~L}: \mathrm{HCl} 37 \% 5.2 \mathrm{~mL}, \mathrm{FeSO}_{4} \cdot 7 \mathrm{H}_{2} \mathrm{O} 1.5 \mathrm{~g}$, $\mathrm{ZnSO}_{4} \cdot 7 \mathrm{H}_{2} \mathrm{O} 0.08 \mathrm{~g}, \mathrm{MnCl}_{2} \cdot 4 \mathrm{H}_{2} \mathrm{O} 0.1 \mathrm{~g}, \mathrm{H}_{3} \mathrm{BO}_{3} 0.3 \mathrm{~g}, \mathrm{CoCl}_{2} \cdot 6 \mathrm{H}_{2} \mathrm{O} 0.19 \mathrm{~g}, \mathrm{CuSO}_{4} 0.004 \mathrm{~g}$, $\mathrm{NiCl}_{2} \cdot 6 \mathrm{H}_{2} \mathrm{O} 0.024 \mathrm{~g}, \mathrm{Na}_{2} \mathrm{MoO}_{4} \cdot 2 \mathrm{H}_{2} \mathrm{O} 0.036 \mathrm{~g}$ ), 860 water. A stock solution of the three PAHs dissolved in acetone $(120 \mu \mathrm{g} / \mathrm{mL})$ was added to test tubes containing $4 \mathrm{~mL}$ of MSM to reach a final concentration of $2 \mu \mathrm{g}$ of PAHs per ml medium. The test tubes were left uncapped for $30 \mathrm{~min}$ to allow evaporation of the acetone prior to the microbial inoculation inside a laminar sterile hood.

To prepare the bacterial inoculants, strains were cultivated in 1/10 strength 869 liquid medium for two days, harvested by centrifugation $\left(4000 \times \mathrm{g}, 15 \mathrm{~min}, 4{ }^{\circ} \mathrm{C}\right)$, washed two times and re suspended in $10 \mathrm{mM} \mathrm{MgSO}_{4}$ to an optical density of 1.0 at $600 \mathrm{~nm}$ (about $10^{7}-10^{8}$ cells per mL). Tubes inoculated with $100 \mu \mathrm{L}$ of each bacterial strain suspension were incubated at $28{ }^{\circ} \mathrm{C}$ and 150 rpm for two, four and seven days. Non-inoculated tubes with MSM were used as a control and four replicates of each treatment were prepared.

PAHs were extracted with $10 \mathrm{~mL}$ of hexane added to each test tube in an end-over-end shaker for $30 \mathrm{~min}$. Extracts were dried with anhydrous $\mathrm{Na}_{2} \mathrm{SO}_{4}$ and then stored at $-20{ }^{\circ} \mathrm{C}$ for posterior chromatographic analysis.

The concentration of PAHs was determined using a gas chromatograph (Varian 450-GC) and a mass spectrometer with ion trap (Varian 220-MS) equipped with an automatic sampler (CP-8400, Varian Inc., Palo Alto, CA, USA). The split/splitless injector worked at $300{ }^{\circ} \mathrm{C}$ and in splitless mode. Sample injection volume was $1 \mu \mathrm{L}$. The chromatographic column was a Thermo Trace Gold TG-5SILMS (30 m x $0.25 \mathrm{~mm} \times 0.25 \mu \mathrm{l}$ ) of $5 \%$ phenyl methyl polysiloxane. The column oven temperature was varied as follows: $60^{\circ} \mathrm{C}$ held for $5 \mathrm{~min}$, followed by an increase of $8{ }^{\circ} \mathrm{C}$ 
$\min ^{-1}$ up to $300{ }^{\circ} \mathrm{C}$ which was held for $4 \mathrm{~min}$. The carrier gas was helium at constant flow of 1.5 $\mathrm{mL} \min ^{-1}$

The mass spectrometer operated in MS/MS mode, ionization of the molecules was carried out by electronic impact $(\mathrm{EI})$ and the transfer line temperature and the ion trap temperature was fixed at $280^{\circ} \mathrm{C}$ and at $220^{\circ} \mathrm{C}$, respectively.

\subsection{Influence of a biosurfactant on PAH availability}

The potential effect of a microbial biosurfactant on the soil PAHs availability was tested using a cell free culture supernatant as soil extractant. The MR28 strain was cultured in 1/10 strength 869 liquid medium $\left(30{ }^{\circ} \mathrm{C}, 150 \mathrm{rpm}\right)$ for two days, and then centrifuged at $9,000 \times g$ for $10 \mathrm{~min}$. The supernatant was separated and filtered at $0.22 \mu \mathrm{m}$ to remove bacterial cells.

Soil from the Pierrelaye site was air-dried and sieved to $<2 \mathrm{~mm}$. Four $\mathrm{g}$ of soil were placed in separate glass test tubes sterilized (Alvarez et al., 2015) and extracted with $10 \mathrm{~mL}$ of the filtered culture supernatant. The extraction was performed by shaking the tubes at $150 \mathrm{rpm}, 30{ }^{\circ} \mathrm{C}$ for five days. Control tubes were prepared in parallel with soil samples treated with 869 liquid medium (1/10 strength) filtered at $0.22 \mu \mathrm{m}$ instead of culture supernatant. Four replicates of each treatment were performed. The soil extracts were separated from soil particles by centrifugation $(9,000 \times g$, $10 \mathrm{~min}, 4^{\circ} \mathrm{C}$ ) and the PAHs in the extracts were obtained with $10 \mathrm{ml}$ of hexane by $60 \mathrm{~min}$ of agitation in an end-over end shaker. PAHs in hexane were determined as explained above.

\section{Results}

3.1 Abundance, identification and phylogenetic analysis of cultivable rhizosphere and root endophytic bacteria 
275 The densities of cultivable bacteria in soil (bulk and rhizosphere) and root endophytes (poplar $v s$. maize) are presented in Table 1. Rhizobacterial densities did not differ significantly between plant species but were up to one logarithmic unit higher than those found in bulk soils. On the other hand, densities endophytes in the root of poplar or maize were not significantly different, but were between two to three logarithmic units lower than rhizobacterial densities (Table 1).

A total of 644 different colony morphotypes was isolated, including 327 rhizobacterial strains, 161 strains from bulk soil and 156 root endophytic strains (108 from NI Populus and 48 from Zea mays). The diversity of cultivable bacteria was estimated using ARDRA and 16S rDNA sequencing. At a similarity of $>90 \%$ ARDRA profiles of isolates from PHYTOPOP were allocated into 64 and 28 ARDRA groups for rhizobacteria associated with Populus and for bacteria from the bulk soil, respectively. In the case of the ARDRA profiles of the bacteria isolated from the rhizosphere of Populus of the different BIOFILTREE plots, were allocated in the following groups: 32 groups for INOC Populus, 33 groups for NI Populus, 28 groups for intercropped Populus and 29 ARDRA groups for bulk soil. Rhizobacterial isolates associated with Zea mays adjacent to the BIOFILTREE plots were classified in 19 ARDRA groups which reflects a lower variety of taxa compared to rhizobacterial isolated from Populus.

The ARDRA profiles of root endophyte isolates from BIOFILTREE plots were divided into 31 and 14 groups for Populus (NI) and Zea mays, respectively. Thus, the cultivable root endophytic community of Populus showed a greater variety of taxa than that of Zea mays.

The 16S rDNA of one representative isolate per ARDRA group was partially sequenced. Gram-positive and Gram-negative bacteria were adequately represented in samples from both PHYTOPOP and BIOFILTREE plots (Table 2). In the PHYTOPOP field trial, isolates belonging to the phylum Actinobacteria dominated the collections obtained from both the Populus rhizosphere and the bulk soil. Within this phylum, most of the isolates were classified as 
Streptomyces, although the genus Rodococcus was also well represented in the rhizosphere of

300 Populus. Firmicutes was the second most dominant phylum in the PHYTOPOP samples. In both the Populus rhizosphere and the bulk soil, most of the isolated Firmicutes belonged to the genera Bacillus or Paenibacillus. Proteobacterial strains were also found: $19 \%$ of the rhizobacterial isolates associated with Populus and $<10 \%$ of strains from the bulk soil. The variety of Proteobacteria was higher in the rhizobacterial community of Populus in which isolates belonging to the Alpha, Beta- and Gamma-proteobacteria were found. Gamma-proteobacteria was not represented in the collection of the bulk soil.

The collections of isolates obtained from the rhizosphere of Populus growing in the BIOFILTREE plots were also dominated by members of the phylum Actinobacteria. Actinobacteria isolated from the rhizosphere of NI Populus grown in monocultures mainly belonged to the genera Streptomyces, Rhodococcus and Arthrobacter. On the other hand, in the collections of INOC or intercropped Populus, these genera, in particular Streptomyces, were also represented but the variety of Actinobacteria was higher: members of the genera Microlunatus, Nocardioides, Micrococcus, and Microbacterium were identified in the rhizosphere of INOC Populus whereas Microbacterium, Kribbella, Knoella and Agromyces were found in the rhizobacterial community of intercropped Populus. By comparing the Populus plots and intercropped Populus plots, the genera Kribella and Agromyces were only found in the later. In the collections of NI and INOC Populus grown in monoculture, Firmicutes were mainly represented by Bacillus strains, while in the samples collected in intercropped Populus plots, the three genera Paenibacillus, Bacillus and Lysinibacillus were similarly represented.

Cultivated Proteobacteria from the rhizosphere of Populus included members of the Alpha-, Beta- and Gamma- classes and the variety of taxa was higher in NI than in INOC Populus. In fact, strains of the Rhizobiales, Ensifer, Pseudochrobactrum and of Lysobacter were isolated only from NI samples. The collection obtained from the rhizosphere of intercropped Populus plots included 
Alpha and Betaproteobacteria; however, most of the isolates were affiliated to genera different than those found in monoculture plots. In the intercropped Populus plots, strains of the Rhizobiales, Devosia, Mesorhizobium and Rhizobium represented about 1/3 of the cultivated Proteobacteria. Regarding the phylum Bacteriodetes, strains of Flavobacterium and Chitinophaga were cultivated from NI Populus rhizosphere and isolates of Pedobacter were obtained from INOC plots. Bacteroidetes were absent in the collection of intercropped Populus (Table 2).

Unlike the rhizobacterial communities of Populus, in the rhizosphere of maize grown on the BIOFILTREE plots, Proteobacteria predominated, while a lower percentage of Actinobacteria was found (Table 2). The percentage of isolates affiliated to both Firmicutes and Bacteroidetes was 12.5\%. The variety of Proteobacteria and Actinobacteria was lower in maize rhizosphere than in Populus rhizosphere. Proteobacteria of the Alpha-, Beta- and Gamma classes were isolated and the strains were classified in five different genera: Rhizobium, Variovorax, Duganella, Pseudomonas and Lysobacter. The isolated Actinobacteria were classified as Streptomyces, Rhodococcus and Arthrobacter. The Bacteroidetes and Firmicutes were only represented by members of the genera Flavobacterium and Bacillus, respectively.

The taxonomic breakdown of the root endophytic communities of NI Populus and Zea mays from BIOFILTREE plots was in line with that observed in corresponding rhizosphere soils: $45 \%$ of the root endophytes of Populus were classified as Proteobacteria, 32.3\% as Actinobacteria and $23 \%$ as Firmicutes, while the maize root endophytes were clearly dominated by members of the Proteobacteria (75\%). In maize root the proportion of isolates classified as Actinobacteria and Firmicutes were $7 \%$ and $8 \%$, respectively (Table 2).

\subsection{Plant growth-promoting characteristics of rhizosphere and root endophytic bacteria}


The majority of the isolates obtained from Populus and maize plants had at least one of the PGP traits tested (Supp. Fig. 1A). Soil rhizosphere bacteria were generally able to produce IAA (>75\% of all isolates) and the higher IAA-producers were mostly associated with Populus rather than Zea mays. However, the majority of these bacteria produced low levels of IAA $(<5 \mu \mathrm{g} / \mathrm{mL})$, while the higher IAA-producers were mainly associated with Populus rather than Zea mays. In addition, greatest number of higher IAA-producers was observed in the intercropped Populus plots (8 strains produced 5-20 $\mu \mathrm{g} / \mathrm{mL}$ IAA and these were identified as Bacillus sp., Rhizobium sp. and Streptomyces sp.). In contrast, maize rhizobacteria harboured a greater number of bacterial strains producing siderophore (approx. $75 \%$ of isolates). Only $30 \%$ of the isolates obtained from intercropped Populus plots showed this trait. P-solubilizers were predominantly associated with INOC Populus (no P-solubilizers were found in NI Populus) or with maize. The ability to produce biosurfactants was less common among isolate collections: between 5 to $20 \%$ of rhizosphere soil isolates exhibited this trait, and the greatest number of biosurfactant-producing strains were found in rhizosphere soil of INOC Populus or maize. In general, between 30 and $60 \%$ of isolates were able to grow in the presence of $\mathrm{Cd}, \mathrm{Cu}, \mathrm{Pb}$ or $\mathrm{Zn}$ (Supp. Fig. 1B).

In the case of root endophytes, $20-25 \%$ of root isolates were strains producing siderophore (Supp. Fig. 1A). P-solubilisers were again more associated with roots of Zea mays than Populus, and up to $40 \%$ of maize root endophytes were able to solubilise mineral phosphate. Producers of biosurfactants were also less frequent and were mainly associated with Populus and identified as Bacillus. Only two strains isolated from maize roots were capable of producing biosurfactants and were identified as Rhizobium and Pseudomonas.

The most frequently observed PGP trait was the ability to produce IAA (although the majority of the strains produced $<5 \mu \mathrm{g} / \mathrm{mL}$ IAA), and a higher number of these IAA-producing strains were associated with Populus rather than maize. With the exception of $\mathrm{Cu}$, metal-resistant strains were 
more frequent in root endophytes from Populus than maize (50-60\% of Populus isolates could grow in the presence of $\mathrm{Cd}, \mathrm{Pb}$ and $\mathrm{Zn}$ compared to $15-20 \%$ of maize isolates) (Supp. Fig. 1B).

\subsection{PAHs degradation}

Bacterial strains belonging to different collection of isolates were evaluated for their ability to degrade phenanthrene, fluoranthene and pyrene as the only $\mathrm{C}$ source. Isolates showing at least two PGP traits (including biosurfactant production) as well as at least one metal tolerance were selected for this purpose (Table 3).

Thus, eleven bacterial isolates including endophyte, rhizospheric and bulk soil strains were assessed for their ability to degrade PAHs. Mean concentrations of phenanthrene, fluoranthene and pyrene in the non-inoculated medium were $1248.6 \pm 53.1 \mu \mathrm{g} / \mathrm{L}, 1531.5 \pm 119.6 \mu \mathrm{g} / \mathrm{L}$ and $1726.9 \pm$ 131.4 $\mu \mathrm{g} / \mathrm{L}$, respectively (Figure 1). The mean phenanthrene concentration decreased after seven days of testing with most of the strains. The final concentrations were between $815.3 \pm 182.6 \mu \mathrm{g} / \mathrm{L}$ and $1236.2 \pm 88.6 \mu \mathrm{g} / \mathrm{L}$; however, the differences were no statistically significant compared to the non-inoculated medium $(p>0.05)$ (Figure 1A). A notable exception was recorded by the strain Bacillus sp. B32.23, which by the fourth day of cultivation exhibited a significant decrease in phenanthrene concentration $(758.0 \pm 111.7 \mu \mathrm{g} / \mathrm{L} v s$ 1248.6 $\pm 53.1 \mu \mathrm{g} / \mathrm{L}$, in B32.23 tubes and in the non-inoculated control, respectively) $(p<0.05)$. On the fourth day of the experiment, the observed decrease in fluoranthene concentration was even more pronounced especially in the case of the strain Bacillus sp. B32.23 (773.6 $\pm 136.9 \mu \mathrm{g} / \mathrm{L}$ residual fluoranthene, $p<0.05)$. At the end of the incubation, the strains Streptomyces sp. Sk.2012, Bacillus sp. Sk1.23, Rhodococcus sp. Sk12.6, Microbacterium sp. Sk11.4 and Bacillus sp. Sk2.3 also reduced the fluoranthene concentration in the culture media $(p<0.05)$. In the case of these isolates pronounced fluoranthene dissipation took place between day four and day seven of incubation (Figure 1B). Again, at the end of the 
experiment, the lowest fluoranthene concentration $(734.8 \pm 347.0 \mu \mathrm{g} / \mathrm{L})$ was found in tubes inoculated with Bacillus sp. B32.23, although similar concentration of residual fluoranthene was detected in tubes inoculated with the strains Streptomyces sp. Sk.20.12, Bacillus sp. Sk1.23, Rhodococcus sp. Sk12.6, Microbacterium sp. Sk11.4 and Bacillus sp. Sk2.3 strains ( $p>0.05)$.

A significant decrease in the pyrene concentration was observed in the presence of the strain Bacillus sp. B32.23 on the second day of the incubation (Fig. 1C) $(p<0.05)$. On the fourth day, the pyrene concentration was also significantly reduced by Pseudomonas sp. MR47 and Sphingomonas sp. SR62. In addition to Sphingomonas sp. SR62 and Bacillus sp. B32.23 strains, a pronounced decrease in residual pyrene was recorded towards the end of the experiment in tubes inoculated with strains Rhizobium sp. MR28, Microbacterium sp. Sk11.4, Rhodococcus sp. Sk12.6, Bacillus sp. Sk1.23, Streptomyces sp. Sk20.12 and Bacillus sp. Sk2.3. As in the case of fluoranthene, the dissipation of pyrene by these isolates was only detected at the end of the incubation. For instance, in the case of strain Sk11.4, pyrene concentration dropped sharply from $1723.0 \pm 49.5 \mu \mathrm{g} / \mathrm{L}$ at day four, to $968.0 \pm 191.6 \mu \mathrm{g} / \mathrm{L}$ at day seven. The lowest residual pyrene concentration was detected in the presence of Bacillus sp. B32.23 strain $(843.1 \pm 407.3 \mu \mathrm{g} / \mathrm{L})$, although this value was not significantly different that those observed for isolates MR28, Sk11.4, Sk12.6, Sk1.23 and Sk20.12 $(p>0.05)$.

\subsection{Influence of a biosurfactant on PAH availability}

The maize-endophyte strain Rhizobium sp. MR28 was selected for its high capacity to produce bioemulsifiers. Thus, the cell-free culture supernatant of Rhizobium sp. MR28 was evaluated as a soil extractant to test if bioemulsifiers potentially released to the growth medium could increase the bioavailability of PAHs in Pierrelaye's soil. Nine different PAHs were detected in the soil extracts, and the concentration of four of them, namely naphthalene, fluorine, anthracene and 
phenanthrene was significantly higher in extracts obtained from MR28 cell-free growth medium than in those obtained with sterile culture medium (control) $(p<0.05)$ (Fig. 2).

\section{Discussion}

The use of microorganisms for treating soils contaminated with TM or organic compounds is an environmentally safe technology which can be improved by plants via the stimulation of microbial growth (Baoune et al., 2019). In the present study, the cultivable bacterial diversity associated with plants established in a mixed contaminated site in Pierrelaye (France) under different SRC-based phytomanagement options was evaluated.

Rhizobacterial densities did not differ significantly between plant species (poplar vs maize) but were up to one logarithmic unit higher than those found in bulk soils. This is a common observation, which can be related, among many other factors with a greater availability of carbon in the rhizosphere (Kidd et al., 2008). The main driver for the rhizosphere effect is the massive root supply of organic substrates to the soil, which can increase the bioavailability of PAHs but also induce a selection of rhizospheric microbial inhabitants (Arslan et al., 2014;

438 Kidd et al., 2009). Root exudates and mucilage-derived nutrients attract large numbers of organisms to the rhizosphere environment. However, the endophytic competence/colonization is limited to specific bacterial species (Durand et al., 2017). Densities of endophytes in the root of poplar or maize were not significantly different, but were between two to three 442 logarithmic units lower than in the rhizosphere. The lower diversity of the endophytic 443 communities compared to soil communities can be explained by the oligotrophic environment 444 present inside plants, leading to a restriction of bacteria capable of using the available resources (Baoune et al., 2018). 
According to the partially sequenced $16 \mathrm{~S}$ rDNA, both Gram-positive and Gram-negative bacteria were widely represented in the samples from the PHYTOPOP and BIOFILTREE trials suggesting that the variety of different taxa may reflect the adaptation of the community to the contaminated soil of Pierrelaye over several decades (Bourceret et al., 2016). The dataset obtained for the roots and soil samples in this work corroborates other previous studies carried out at the same site (Pierrelaye) on native tree species (poplar and willow), revealing the dominance of Proteobacteria and Actinobacteria (Durand et al., 2017; Foulon et al., 2016).

The collection of isolates obtained from the rhizosphere of Populus was dominated by members of the phylum Actinobacteria. Gram-positive bacteria, and in particular the Actinobacteria, have frequently been found to dominate cultivable bacterial communities of TM contaminated soils and natural soils rich in TM, such as serpentine soils (Álvarez-López et al., 2016; Becerra-Castro et al., 2012). Several actinobacterial inoculants, selected for their PGP traits, have been used successfully in bioaugmentation assays to enhance TM extraction (phytoextraction and phytomining) (Becerra-Castro et al., 2013; Cabello-Conejo et al., 2014). Actinobacteria are Pierrelaye site were observed compared to unplanted soils or to baseline values prior to the implementation of the phytomanagement trials (Foulon et al., 2016a; Ciadamidaro et al., 2017). Mycorrhizal inoculation also significantly increased the biomass yield of the Populus Skado clone at the Pierrelaye site (Ciadamidaro et al., 2017). Foulon et al. (2016a) reported that higher bacterial diversity and richness indices were observed in poplar soils compared to unplanted soils, which is in agreement with the results of the present study. In the present study, the bacterial communities associating with the INOC Populus were found to be significantly different from the 
the same (Actinobacteria, Bacteroidetes, Firmicutes and Proteobacteria) but, surprisingly, the variety of cultivable bacteria was lower when the trees had been previously inoculated (INOC) by a mycorrhizal consortium. Inoculation led to a decrease in the relative abundance of members of the Bacteroidetes and Proteobacteria, and to an increase in those belonging to Firmicutes.

A clear enrichment in the Proteobacteria phylum in the endospheric compartment has been recorded in previous publications (Afzal et al., 2014). Such as in the case of the rhizosphere, a higher variety of isolates was observed in the root endophytic community of Populus compared to that of maize. Blain et al. (2017) characterized the endophytic root bacteria associated with the natural vegetation growing on a hydrocarbon-contaminated site. In agreement with our results, the authors found that the bacterial orders more represented within these communities were Rhizobiales, Pseudomonadales, Burkholderiales, Sphingomonadales and Actinomycetales. Members of these orders seem to be well adapted to PAH contaminated soils and useful for remediation strategies (Blain et al., 2017).

Bioaugmentation with PGP and PAH-degrading bacterial strains has been shown to improve dissipation of PAHs in contaminated soils. Recent studies have identified rhizosphere and endophytic bacteria which have the potential to degrade PAH and are widely distributed in the organs and rhizosphere of plants growing in PAH-polluted sites (Baoune et al., 2018; Pawlik et al., 2020). Nevertheless, studies on endophytes or rhizosphere bacteria with PAH degradation capacity are still rare. In the present work, several bacterial strains were evaluated for their ability to degrade phenanthrene, fluoranthene and pyrene. As was previously mentioned, all the strains selected to evaluate their capacity to degrade PAHs showed at least two PGP traits and were tolerant to at least one TM. Among the fluoaranthene degrading bacteria, the actinobacterium Streptomyces sp. Sk2012 was found to be able to produce the highest IAA amount among all the isolates assessed. The IAA is the most important phyto-hormone responsible for root development stimulating plant cell proliferation and plant cell elongation (Glick, 2014). Another fluoranthene 
degrading actinobacterium, Rodococcus Sk12.6, was the only soil strain capable of solubilizing phosphate, a rare trait for members of the phylum as they are rarely described for their ability to produce the organic acid responsible for the solubilization of phosphate (Jog et al., 2014). It is important to note that two endophytes (Sphingomonas SR62 isolated from Populus and Rhizobium sp. MR28 isolated from maize) were among the best pyrene degrading strains. According to Afzal et al. (2014), endophytic bacteria with PGP and pollutant degradation traits performed better than bacteria with only one of these characteristics. In addition, the PAH-degrading activity could be considered itself as a PGP characteristic, because contaminants, have a negatively effect on plant development.

A wide range of bacteria are able to degrade low molecular weight PAHs, while relatively few microorganisms are able to degrade high molecular weight recalcitrant PAHs (Ghosal et al., 2016). Interestingly, although fluoranthene and pyrene have been used as a model of high molecular weight PAHs, several isolates studied here were able to dissipate these compounds. On the other hand, one of the most frequently cited and generally accepted constraints for PAHs bioremediation is the low water solubility of these compounds which results in low bioavailability for pollutantdegrading organisms (Makkar and Rockne 2003). It has been hypothesized that the synthesis and release of bioemulsifying compounds is one of the numerous microbial adaptations to access poorly soluble substrates such as hydrocarbons (Uzoigwe et al., 2015). In the present work, the cell-free growth medium of the pyrene-degrading endophyte Rhizobium sp. MR28 showed higher capacity for solubilising PAHs from contaminated Pierrelaye soil than sterile culture medium used as control. Hickey et al. (2007) found that biosurfactants considerably increased the desorption of PAHs from soil and improved their biodegradation by Pseudomonas alcaligenes PA-10. Kuppusamy et al. (2017) isolated two strains belonging to the genera Bacillus and Pseudomonas from animal faeces which completely degraded phenanthrene, pyrene and benzo-a-pyrene after 6 , 
7 and 40-50 days, respectively. These isolates were found to produce a biosurfactant of rhamnolipid nature upon PAH degradation.

In a phytoremediation scenario, endophytic bacteria with specific metabolic capabilities might be able to degrade organic pollutants and reduce both phytotoxicity and evapotranspiration of volatile compounds. For instance, Sheng et al. (2008) found that the endophytic Enterobacter sp. 12J1 could efficiently remove pyrene and improve maize and wheat growth in pyrene contaminated soils. Recently, Pawlik et al., (2020) demonstrated that in an aged petroleum hydrocarbon polluted soil, the method of inoculation of endophytic strains determines the efficiency of the phytoremediation process.

The inoculation of plants grown in mixed contaminated sites such as Pierrelaye with the group of bacterial strains studied could be a successful phytotechnology to improve SRC-based phytomanagement options.

\section{Conclusion}

The cultivable bacterial diversity associated with trees under different SRC-based phytomanagement options in a PAH and TM contaminated site in Pierrelaye (France) was assessed.

The collections of isolates were dominated by Proteobacteria and Actinobacteria. Differences in taxonomic composition were observed between plant species and depending on the phytomanagement option. A greater variety of taxa was found in the endophytic community of Populus than inside the root of Zea mays.

On the basis of the PGP characteristics analysed, the tolerance to TM and the ability for increasing the dissipation of different PAHs, the following strains could be selected as potential interesting candidates for further re-inoculation experiments: Bacillus sp. B32.23, Streptomyces 
sp. Sk.2012, Rhodococcus sp. Sk12.6, Microbacterium sp. Sk11.4, Bacillus sp. Sk1.23, Bacillus sp. Sk2.3, Sphingomonas sp. SR62, Pseudomonas sp. MR47 and Rhizobium sp. MR28.

\section{Acknowledgements}

This work was supported by the Agence Nationale de la Recherche (ANR) under the PRECODD (ANR-06-ECOT-O15-01-PHYTOPOP) and the Blanc International (ANR-10-INTB-1703-01BIOFILTREE) projects.

This article is dedicated to the memory of our dearly missed colleague and friend Petra Kidd (1972-2020).

\section{References}

Afzal, M., Khan, Q.M., Sessitsch, A., 2014. Endophytic bacteria: prospects and applications for the phytoremediation of organic pollutants. Chemosphere 117, 232-242. Doi: 10.1016/ j.chemosphere.2014.06.078.

Alvarez, A., Benimeli, C.S., Saez, J.M., Giuliano, A., Amoroso, M.J., 2015. Lindane removal using Streptomyces strains and maize plants: a biological system for reducing pesticides in soils. Plant Soil 395, 401-413. Doi: 10.1007/s11104-015-2575-5.

Álvarez, A., Benimeli, C.S., Sáez, J.M., Giuliano, A., Amoroso, M.J., 2015. Lindane removal using Streptomyces strains and maize plants: a biological system for reducing pesticides in soils. Plant Soil 395, 401-413. Doi: 10.1007/s11104-015-2575-5.

Alvarez, A., Catalano, S.A., Amoroso, M.J., 2013. Heavy metal resistant strains are widespread along Streptomyces phylogeny. Mol. Phylogenet. Evol. 66, 1083-1088. doi: 10.1016/j.ympev.2012.11.025. 
Álvarez, A., Saez, J.M., Davila Costa, J.S, Colin, V.L., Fuentes, M.S., Cuozzo, S.A., et al., 2017. Actinobacteria: current research and perspectives for bioremediation of pesticides and heavy metals. Chemosphere 166, 41-62. Doi: 10.1016/j.chemosphere.2016.09.070.

Álvarez-López, V., Prieto-Fernández, C., Becerra-Castro, C., Monterroso, C., Kidd, P.S., 2016. Rhizobacterial communities associated with the flora of three serpentine outcrops of the Iberian Peninsula. Plant Soil 403, 233-252. Doi: 10.1007/s11104-0152632-0.

Arslan, M., Afzal, M., Amin, I., Iqbal, S., Khan, Q.M., 2014. Nutrients can enhance the abundance and expression of alkane hydroxylase CYP153 gene in the rhizosphere of ryegrass planted in hydrocarbon-polluted soil. PLoS One 9, e111208. Doi: 10.1371/journal.pone.0111208.

Baoune, H., Aparicio, J.D., Acuña, A., El Hadj-khelil, A.O., Sanchez, L., Polti, M.A., et al., 2019. Effectiveness of the Zea mays-Streptomyces association for the phytoremediation of petroleum hydrocarbons impacted soils. Ecotoxicol. Environ. Saf. 184, 109591. Doi: 10.1016/j.ecoenv.2019.109591.

Baoune, H., Ould El Hadj-Khelil, A., Pucci, G., Sineli, P., Loucif, L., Polti, M.A., 2018. Petroleum degradation by endophytic Streptomyces spp. isolated from plants grown in contaminated soil of southern Algeria. Ecotoxicol. Environ. Saf. 147, 602-609. Doi: 10.1016/j.ecoenv.2017.09.013.

Becerra-Castro, C., Kidd, P., Kuffner, M., Prieto-Fernández, A., Hann, S., Monterroso, C., et al., 2013. Bacterially induced weathering of ultramafic rock and its implications for phytoextraction. Appl. Environ. Microbiol. 79, 5094-5103. Doi: 10.1128/AEM.00402-13. 
Becerra-Castro, C., Monterroso, C., Prieto-Fernández, A., Rodríguez-Lamas, L., LoureiroViñas, M., Acea, M.J. et al., 2012. Pseudometallophytes colonising $\mathrm{Pb} / \mathrm{Zn}$ mine tailings: a description of the plant-microorganism-rhizosphere soil system and isolation of metal-tolerant bacteria. J. Hazard. Mater. 217-218, 350-359. Doi: 10.1016/j.jhazmat.2012.03.039.

Blain, N.P., Helgason, B.L., Germida, J.J., 2017. Endophytic root bacteria associated with the natural vegetation growing at the hydrocarbon-contaminated Bitumount Provincial Historic site. Can. J. Microbiol. 63, 502-515. Doi: 10.1139/cjm-2017-0039.

Boopathy, R., 2000. Factors limiting bioremediation technologies. Bioresour. Technol. 74, 63-67. Doi: 10.1016/S0960-8524(99)00144-3.

Bourceret, A., Cébron, A., Tisserant, E., Poupin, P., Bauda, P., Beguiristain, T., et al., 2016. The Bacterial and Fungal Diversity of an Aged PAH- and Heavy Metal-Contaminated Soil is Affected by Plant Cover and Edaphic Parameters. Microb. Ecol. 71, 711-724. Doi: $10.1007 / \mathrm{s} 00248-015-0682-8$.

Cabello-Conejo, M.I., Becerra-Castro, C., Prieto-Fernández, A., Monterroso, C., SaavedraFerro, A., Mench, M. et al., 2014. Rhizobacterial inoculants can improve nickel phytoextraction by the hyperaccumulator Alyssum pintodasilvae. Plant Soil 379, 3550. Doi: $10.1007 / \mathrm{s} 11104-0142043-7$.

Carmichael, L.M., Pfaender, F.K., 1997. The effect of inorganic and organic supplements on the microbial degradation of phenanthrene and pyrene in soils. Biodegradation 8,1 13. Doi: $10.1023 / \mathrm{a}: 1008258720649$.

Cerniglia, C.E., 1992. Biodegradation of polycyclic aromatic hydrocarbons. Biodegradation 3, 351-368. Doi: 10.1007/BF00129093.

Ciadamidaro, L., Girardclos, O., Bert, V., Zappelini, C., Yung, L., Foulon, J., et al., 2017. Poplar biomass production at phytomanagement sites is significantly enhanced by 
mycorrhizal inoculation. Environ. Exp. Bot. 139, 48-56. Doi: 10.1016/j.envexpbot.2017.04.004.

Cole, J.R., Wang, Q., Cardenas, E., Fish, J., Chai, B., Farris, R.J. et al., 2009.The Ribosomal Database Project: improved alignments and new tools for rRNA analysis. Nucleic Acids Res. 37, D141-D145. Doi: 10.1093/nar/gkn879.

Cox, C.D., 1994. Deferration of laboratory media and assays for ferric and ferrous ions. Methods Enzymol. 235, 315-329. Doi: 10.1016/0076-6879(94)35150-3.

Chalot, M., Girardclos, O., Ciadamidaro, L., Zappelini, C., Yung, L., Durand, A., et al., 2020. Poplar rotation coppice at a trace element-contaminated phytomanagement site: A 10year study revealing biomass production, element export and impact on extractable elements. Sci. Total Environ., 699, 134260. Doi: 10.1016/j.scitotenv.2019.134260.

Chen, C.Y., Baker, S.C., Darton, R.C., 2007. The application of a high throughput analysis method for the screening of potential biosurfactants from natural sources. J. Microbiol. Methods 70, 503-510. Doi: 10.1016/j.mimet.2007.06.006.

Durand, A., Maillard, F., Foulon, J., Hyun, S., Gweon, B.V., Chalot, M., 2017. Environmental Metabarcoding Reveals Contrasting Belowground and Aboveground Fungal Communities from Poplar at a $\mathrm{Hg}$ Phytomanagement Site. Microb. Ecol. 74, 795-809. Doi: 10.1007/s00248-017-0984-0.

Foulon, J., Zappelini, C., Durand, A., Valot, B., Blaudez, D., Chalot, M., 2016a. Impact of poplar -based phytomanagement on soil properties and microbial communities in a metal contaminated site. FEMS Microbiol. Ecol. 92, fiw163. Doi: 10.1093/femsec/fiw163.

Foulon, J., Zappelini, C., Durand, A., Valot, B., Girardclos, O., Blaudez, D., Chalot, M., 2016b. Environmental metabarcoding reveals contrasting microbial communities at 
two poplar phytomanagement sites. Sci. Total Environ. 571, 1230-1240. Doi: 10.1016/j.scitotenv.2016.07.151.

Ghosal, D., Ghosh, S., Dutta, T.K., Ahn, Y., 2016. Current state of knowledge in microbial degradation of polycyclic aromatic hydrocarbons (PAHs): a Review. Front. Microbiol. 7, 1369. Doi: 10.3389/fmicb.2016.01369.

Glick, B.R., 2014. Bacteria with ACC deaminase can promote plant growth and help to feed the world. Microbiol. Res. 169, 30-39. Doi: 10.1016/j.micres.2013.09.009.

Gołębiewski, M., Deja-Sikora, E., Cichosz, M., Tretyn, A., Wróbel, B., 2014. 16S rDNA pyrosequencing analysis of bacterial community in heavy metals polluted soils. Microb. Ecol. 67, 635-647. Doi: 10.1007/s00248-013-0344-7.

Hickey, A.M., Gordon, L., Dobson, A.D., Kelly, C.T., Doyle, E.M., 2007. Effect of surfactants on fluoranthene degradation by Pseudomonas alcaligenes PA-10. Appl. Microbiol. Biotechnol. 74, 851-856. Doi: 10.1007/s00253-006-0719-5.

Hickey, A.M., Gordon, L., Dobson, A.D.W., Kelly, C.T., Doyle, E.M., 2007. Effect of surfactants on fluoranthene degradation by Pseudomonas alcaligenes PA-10. Appl. Microbiol. Biotechnol. 74, 851-856. Doi: 10.1007/s00253-006-0719-5.

Jeannin, T., Yung, L., Evon, P., Labonne, L., Ouagne, P., Lecourt, M., et al., 2020. Native stinging nettle (Urtica dioica L.) growing spontaneously under short rotation coppice for phytomanagement of trace element contaminated soils: Fibre yield, processability and quality. Ind. Crop Prod. 145, 111997. Doi: 10.1016/j.indcrop.2019.111997.

Jog, R., Pandya, M., Nareshkumar, G., Rajkumar, S., 2014. Mechanism of phosphate solubilization and antifungal activity of Streptomyces spp. isolated from wheat roots and rhizosphere and their application in improving plant growth. Microbiology 160, 778-788. Doi: 10.1099/mic.0.074146-0. 
Kästner, M., Breuer-Jammali, M., Mahro, B., 1994. Enumeration and characterization of the soil microflora from hydrocarbon-contaminated soil sites able to mineralize polycyclic aromatic hydrocarbons (PAH). Appl. Microbiol. Biotechnol. 41, 267-273. Doi: 10.1007/BF00186971.

Kidd, P., Barceló, J., Bernal, M.P., Navari-Izzo, F., Poschenrieder, C., Shilev, S. et al., 2009. Trace element behaviour at the root-soil interface: implications in phytoremediation. Environ. Exp. Bot. 67, 243-259. Doi: 10. 1016/j.envexpbot.2009.06.013.

Kidd, P., Mench, M., Alvarez-López, V., Bert, V., Dimitriou, I., Friesl-Hanl, W., et al., 2015. Agronomic practices for improving gentle remediation of trace element-contaminated soils. Int. J. Phytoremediat. 17, 1005-1037. Doi: 10.1080/15226514.2014.1003788.

Kidd, P., Prieto-Fernández, A., Monterroso, C., Acea, M.J., 2008. Rhizosphere microbial community and hexachlorocyclohexane degradative potential in contrasting plant species. Plant Soil 302, 233-247 Doi: 10.1007/s11104-007-9475-2.

Kuppusamy, S., Thavamani, P., Venkateswarlu, K., Lee, Y.B., Naidu, R., Megharaj, M., 2017. Remediation approaches for polycyclic aromatic hydrocarbons (PAHs) contaminated soils: technological constraints, emerging trends and future directions. Chemosphere 168, 944-968. Doi: 10.1016/j.chemosphere.2016.10.115.

Lamy, I., van Oort, F., Dère, C., Baize, D., 2006. Use of major- and trace-element correlations to assess metal migration in sandy Luvisols irrigated with wastewater. Eur. J. Soil Sci. 57, 731-740. Doi: 10.1111/j.1365-2389.2005.00765.x.

Makkar. R.S., Rockne, K.J., 2003. Comparison of synthetic surfactants and biosurfactants in enhancing biodegradation of polycyclic aromatic hydrocarbons. Environ. Toxicol. Chem. 22, 2280-2292. Doi: 10.1897/02-472.

Mench, M., Lepp, N., Bert, V., Schwitzguébel, J.P., Gawronski, S.W., Schröder, P., et al., 2010. Successes and limitations of phytotechnologies at field scale: outcomes, 
assessment and outlook from COST Action 859. J. Soils Sed. 10, 1039-1070. Doi: 10.1007/s11368-010-0190-x.

Mench, M., Schwitzguébel, J.P., Schroeder, P., Bert, V., Gawronski, S., Gupta, S., 2009. Assessment of successful experiments and limitations of phytotechnologies: contaminant uptake, detoxification and sequestration, and consequences for food safety. Environ. Sci. Pollut. Res. 16, 876-900. Doi: 10.1007/s11356-009-0252-z.

Mendes, R., Garbeva, P., Raaijmakers, J.M., 2013. The rhizosphere microbiome: significance of plant beneficial, plant pathogenic, and human pathogenic microorganisms. FEMS Microbiol. Rev. 37, 634-663. Doi: 10.1111/1574-6976.12028.

Mergeay, M., Nies, D., Schlegel, H., Gerits, J., Charles, P., Van Gijsegem, F., 1985. Alcaligenes eutrophus $\mathrm{CH} 34$ is a facultative chemolithotroph with plasmid-bound resistance to heavy metals. J. Bacteriol. 162, 328-334. Doi: 10.1128/JB.162.1.328334.1985.

Nautiyal, C.S., 1999. An efficient microbiological growth medium for screening phosphate solubilizing microorganisms. FEMS Microbiol. Lett. 170, 265-270. Doi:10.1111/j.1574-6968.1999.tb13383.x.

Pawlik, M., Płociniczak, T., Thijs, S., Pintelon, I., Vangronsveld, J., Piotrowska-Seget, Z., 2020. Comparison of Two Inoculation Methods of Endophytic Bacteria to Enhance Phytodegradation Efficacy of an Aged Petroleum Hydrocarbons Polluted Soil. Agronomy 10, 1196. Doi: 10.3390/agronomy10081196.

Pottier, M., García de la Torre, V.S., Victor, C., David, L.C., Chalot, M., Thomine, S., 2015. Genotypic variations in the dynamics of metal concentrations in poplar leaves: A field study with a perspective on phytoremediation. Environ. Pollut. 199, 73-82. Doi: 10.1016/j.envpol.2015.01.010. 
Schlegel, H.G., Cosson, J.P., Baker, A.J.M., 1991. Nickel-hyperaccumulating plants provide a niche for nickel-resistant bacteria. Bot. Acta 104, 18-25. Doi: 10.1111/j.14388677.1991.tb00189.x.

Schwyn, B., Neilands, J.B., 1987. Universal chemical assay for the detection and determination of siderophores. Anal. Biochem. 160, 47-56. Doi: 10.1016/00032697(87)90612-9.

Sheng, X., Chen, X., He, L., 2008. Characteristics of an endophytic pyrene-degrading bacterium of Enterobacter sp. 12J1 from Allium macrostemon Bunge. Int. Biodeterior. Biodegrad. 62, 88-95. Doi: 10.1016/j.ibiod.2007.12.003.

Sheng, X.F., Xia, J.J., Jiang, C.Y., He, L.Y., Qian, M., 2008. Characterization of heavy metalresistant endophytic bacteria from rape (Brassica napus) roots and their potential in promoting the growth and lead accumulation of rape. Environ. Pollut. 156, 11641170. Doi: 10.1016/j.envpol.2008.04.007.

Thijs, S., Langill, T., Vangronsveld, J., 2017. The bacterial and fungal microbiota of hyperaccumulator plants: Small organisms, large influence, in: Cuypers, A., Vangronsveld, J. (Eds.), Phytoremediation. Elsevier, Oxford, pp. 43-86.

Uzoigwe, C., Burgess, J.G., Ennis, C.J., Rahman, P.K.S.M., 2015. Bioemulsifiers are not biosurfactants and require different screening approaches. Front. Microbiol. 6, 245. Doi: $10.3389 /$ fmicb.2015.00245.

Vangronsveld, J., Herzig, R., Weyens, N., Boulet, J., Adriaensen, K., Ruttens, A., et al., 2009. Phytoremediation of contaminated soils and groundwater: lessons from the field. Environ. Sci. Pollut. Res. 16, 765-94. Doi: 10.1007/s11356-009-0213-6.

Weyens, N., van der Lelie, D., Taghavi, S., Newman, L., Vangronsveld, J., 2009. Exploiting plant microbe partnerships to improve biomass production and remediation. Trends Biotechnol. 27, 591-598. Doi: 10.1016/j.tibtech.2009.07.006. 
740 Wilson, S.C., Jones, K.C., 1993. Bioremediation of soil contaminated with polynuclear aromatic hydrocarbons (PAHs): a review. Environ. Pollut. 81, 229-249. Doi: 10.1016/0269-7491(93)90206-4.

743

744

Ziegler-Devin, I., Menana, Z., Chrusciel, L., Chalot, M., Bert, V., Brosse, N., 2019. Steam explosion pretreatment of willow grown on phytomanaged soils for bioethanol production. Ind. Crop Prod. 140, 111722. Doi: 10.1016/j.indcrop.2019.111722.

\section{Author contributions}

Petra S. Kidd: investigation, conceptualization, visualization, writing (original draft), funding acquisition

Analía Alvarez: investigation, writing, review and editing, supervision.

Vanessa Álvarez-López: investigation, review and editing.

Andrea Cerdeira-Pérez: investigation.

Beatriz Rodriguez-Garrido: investigation.

Ángeles Prieto-Fernández: review and editing, supervision.

Michel Chalot: investigation, review and editing, supervision, funding acquisition. 
Figure 1. Mean concentrations of PAHs detected in the culture medium after growing a selected group of strains from bulk soil, rhizosphere and roots of poplar and maize plants from Pierrelaye. (A) phenanthrene; (B) fluoranthene; (C) pyrene. The mean concentrations of non-inoculated samples (NI) are indicated by a continuous line. Bars with an asterisk indicate that they were statistically different from the NI control ( $p<0.05$, Tukey's post-test). MR and SR: endophyte strains from maize and poplar Skado (respectively) from the BIOFILTREE plots; Sk: rhizosphere strains from poplar Skado from PHYTOPOP plots; B: strain from bulk soil (PHYTOPOP plots). 
786

787

788

789

790

791

792

793

794

795

796

797

798

799

800

801

802

803

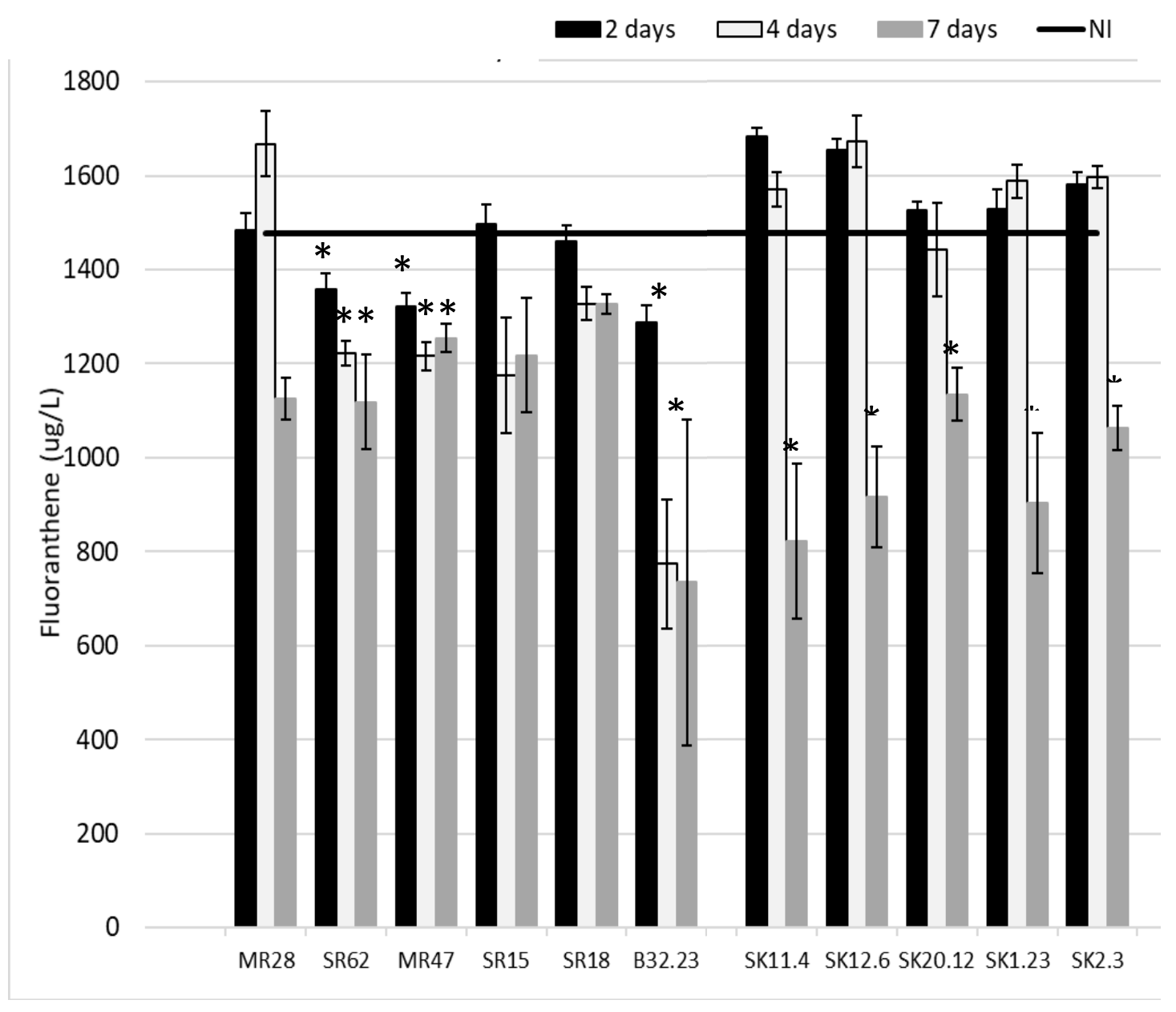

804

805

806

807

808

809 
814

815

816

817

818
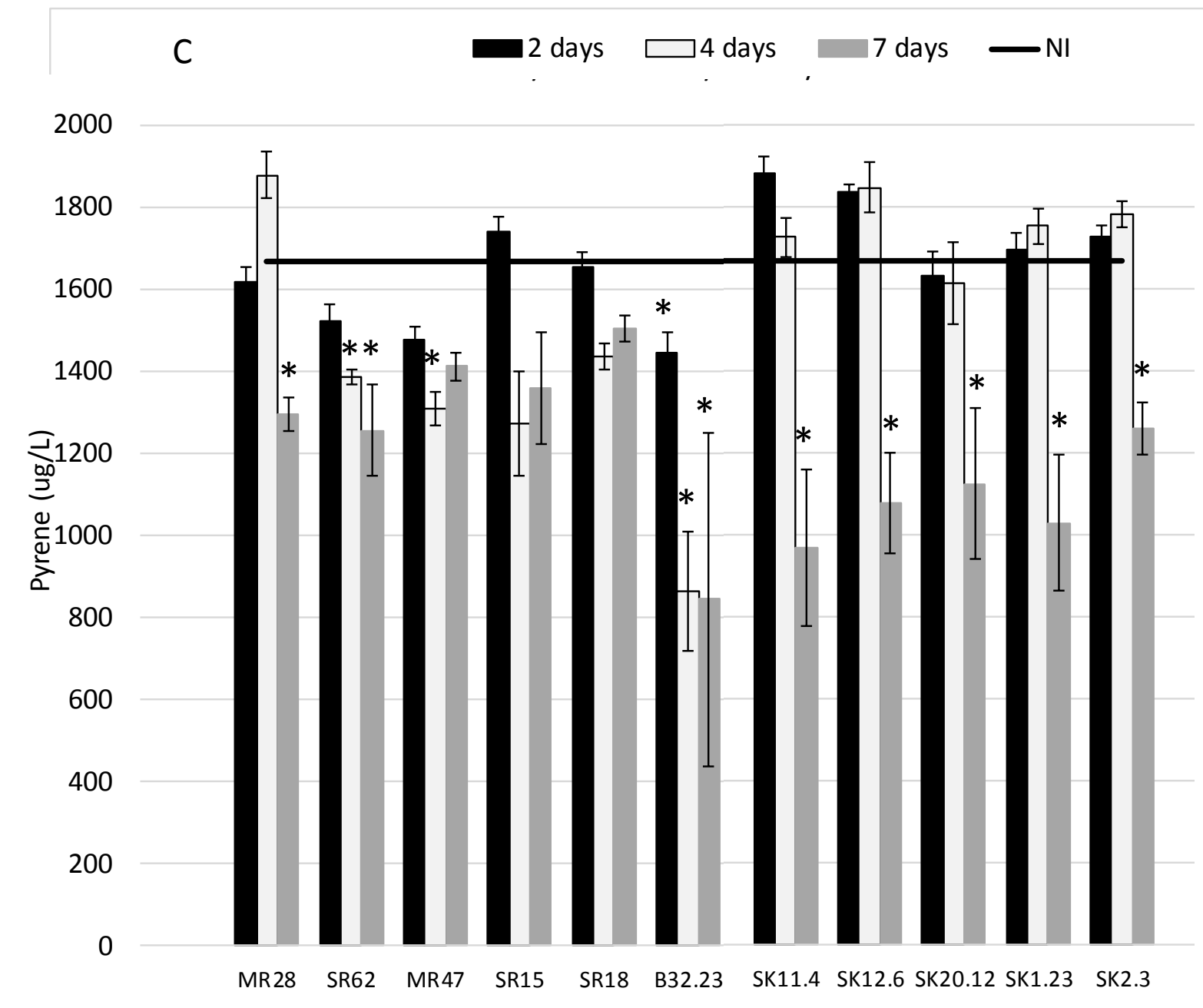
819 Figure 2. PAHs detected before use the cell-free culture supernatant of Rhizobium sp. MR28 as soil extractant, isolated from the Pierrelaye site. Asterisk indicates significant differences 821 among treatments ( $p<0.05$ Tukey's post-test)

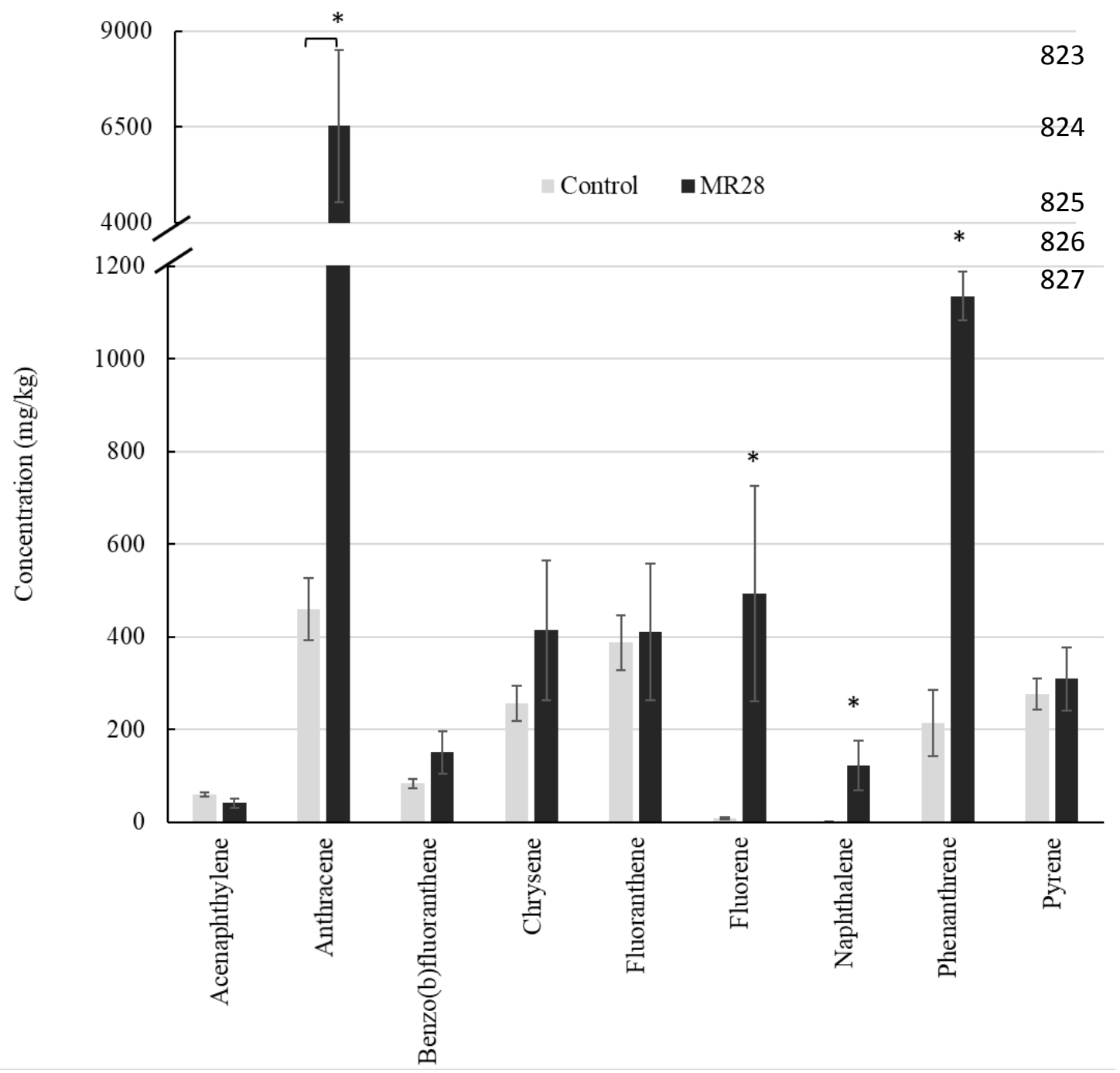


Table 1. Description of samples from Pierrelaye soil which were used for the isolation of

829 bacterial strains.

\begin{tabular}{ll}
\hline Plot and sample name & Description* \\
\cline { 1 - 2 } Phytopop & \\
\cline { 1 - 2 } $\begin{array}{l}\text { Bulk soil } \\
\text { Poplar Skado }\end{array}$ & $\begin{array}{l}\text { Isolation of soil bacteria } \\
\text { Isolation of rhizobacteria }\end{array}$ \\
\hline Biofiltree & \\
\hline Bulk soil & Isolation of soil bacteria \\
Maize & Isolation of rhizobacteria \& root endophytes \\
Poplar Skado NI** & Isolation of rhizobacteria \& root endophytes \\
Poplar Skado INOC** & Isolation of rhizobacteria \\
Poplar Skado/ Alder & Isolation of rhizobacteria
\end{tabular}

830

831 *Five replicates of each sample were studied

832

**NI: non-inoculated plots with mycorrhiza; INOC: inoculated plots with mycorrhiza

833

834

835 
Table 2. Taxomomic affiliation of culturable strains isolated from bulk soil, rhizosphere and

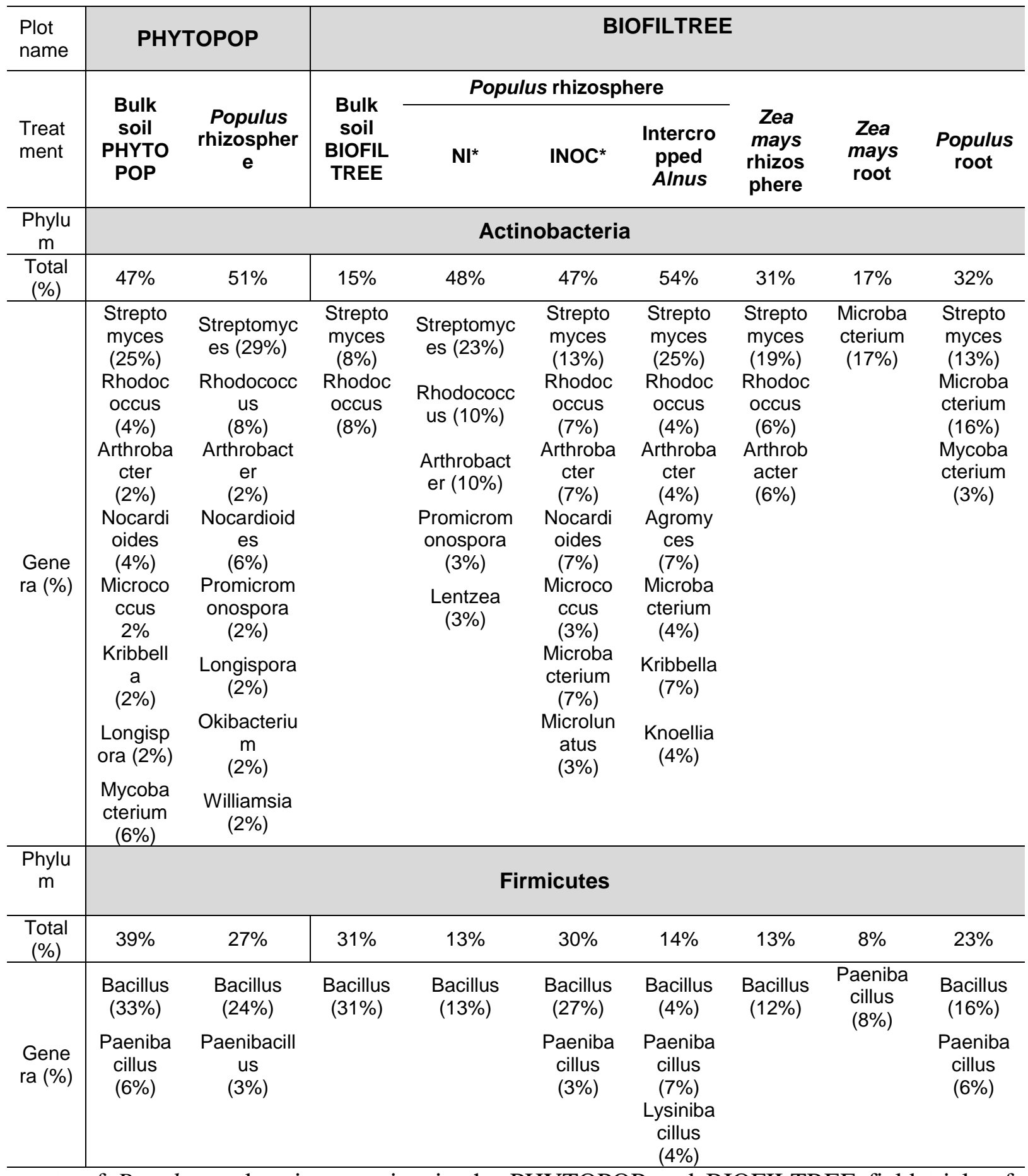

837 roots of Populus and maize growing in the PHYTOPOP and BIOFILTREE field trials of

838 Pierrelaye (France).

839 *NI: non-inoculated plots with mycorrhiza; INOC: inoculated plots with mycorrhiza 


\begin{tabular}{|c|c|c|c|c|c|c|c|c|c|}
\hline \multirow[b]{3}{*}{$\begin{array}{l}\text { Treat } \\
\text { ment }\end{array}$} & \multicolumn{2}{|c|}{ Phytopop } & \multicolumn{7}{|c|}{ Biofiltree } \\
\hline & \multirow[b]{2}{*}{$\begin{array}{c}\text { Bulk soil } \\
\text { Phytopo } \\
\text { p }\end{array}$} & \multirow[b]{2}{*}{$\begin{array}{l}\text { Populus } \\
\text { rhizosphe } \\
\text { re }\end{array}$} & \multirow[b]{2}{*}{$\begin{array}{c}\text { Bulk } \\
\text { soil } \\
\text { Biofil } \\
\text { tree }\end{array}$} & \multicolumn{3}{|c|}{ Populus rhizosphere } & \multirow[b]{2}{*}{$\begin{array}{c}\text { Zea } \\
\text { mays } \\
\text { rhizos } \\
\text { phere }\end{array}$} & \multirow[b]{2}{*}{$\begin{array}{c}\text { Zea } \\
\text { mays } \\
\text { root }\end{array}$} & \multirow[b]{2}{*}{$\begin{array}{l}\text { Populus } \\
\text { root }\end{array}$} \\
\hline & & & & $\mathrm{NI}^{*}$ & INOC* $^{*}$ & $\begin{array}{l}\text { Intercr } \\
\text { opped } \\
\text { Alnus }\end{array}$ & & & \\
\hline
\end{tabular}

841 Table 2 (continuation) 


\begin{tabular}{|c|c|c|c|c|c|c|c|c|c|}
\hline $\begin{array}{c}\text { Phylu } \\
\text { m }\end{array}$ & \multicolumn{9}{|c|}{ Proteobacteria } \\
\hline $\begin{array}{l}\text { Total } \\
(\%)\end{array}$ & $10 \%$ & $19 \%$ & $31 \%$ & $29 \%$ & $20 \%$ & $32 \%$ & $44 \%$ & $75 \%$ & $45 \%$ \\
\hline Class & \multicolumn{9}{|c|}{ a-Proteobacteria } \\
\hline \multirow{6}{*}{$\begin{array}{l}\text { Gene } \\
\text { ra } \\
(\%)\end{array}$} & $\begin{array}{c}\text { Methylob } \\
\text { acterium } \\
(2 \%)\end{array}$ & $\begin{array}{l}\text { Methyloba } \\
\text { cterium } \\
(2 \%)\end{array}$ & $\begin{array}{c}\text { Ensif } \\
\text { er } \\
(15 \% \\
)\end{array}$ & $\begin{array}{l}\text { Pseudochr } \\
\text { obactrum } \\
(3 \%)\end{array}$ & $\begin{array}{c}\text { Sphingopy } \\
\text { xis } \\
(3 \%)\end{array}$ & $\begin{array}{l}\text { Rhizobi } \\
\text { um } \\
(4 \%)\end{array}$ & $\begin{array}{l}\text { Rhizobi } \\
\text { um } \\
(6 \%)\end{array}$ & $\begin{array}{l}\text { Rhizobi } \\
\text { um } \\
(17 \%)\end{array}$ & $\begin{array}{l}\text { Rhizobiu } \\
\text { m (3\%) }\end{array}$ \\
\hline & $\begin{array}{l}\text { Microvirg } \\
\text { a }(2 \%)\end{array}$ & $\begin{array}{c}\text { Microvirga } \\
(2 \%)\end{array}$ & & $\begin{array}{l}\text { Ensifer } \\
(3 \%)\end{array}$ & & $\begin{array}{c}\text { Devosia } \\
(4 \%)\end{array}$ & & & $\begin{array}{c}\text { Devosia } \\
(3 \%)\end{array}$ \\
\hline & $\begin{array}{l}\text { Ensifer } \\
(2 \%)\end{array}$ & $\begin{array}{c}\text { Bosea } \\
(2 \%)\end{array}$ & & $\begin{array}{c}\text { Sphingom } \\
\text { onas } \\
(3 \%)\end{array}$ & & $\begin{array}{l}\text { Mesorhi } \\
\text { zobium } \\
(4 \%)\end{array}$ & & & $\begin{array}{c}\text { Bosea } \\
(6 \%)\end{array}$ \\
\hline & & $\begin{array}{l}\text { Sphingom } \\
\text { onas }(2 \%)\end{array}$ & & & & & & & $\begin{array}{c}\text { Sphingom } \\
\text { onas } \\
(3 \%)\end{array}$ \\
\hline & & $\begin{array}{l}\text { Roseomon } \\
\text { as }(2 \%)\end{array}$ & & & & & & & $\begin{array}{c}\text { Tardiphag } \\
\text { a (10\%) }\end{array}$ \\
\hline & & $\begin{array}{l}\text { Phylobacte } \\
\text { rium }(2 \%)\end{array}$ & & & & & & & \\
\hline Class & \multicolumn{9}{|c|}{$\beta$-Proteobacteria } \\
\hline \multirow{2}{*}{$\begin{array}{l}\text { Gene } \\
\text { ra }(\%\end{array}$} & $\begin{array}{c}\text { Variovor } \\
\text { ax } \\
(2 \%)\end{array}$ & $\begin{array}{c}\text { Cupriavidu } \\
\text { s } \\
(3 \%)\end{array}$ & $\begin{array}{l}\text { Vario } \\
\text { vorax } \\
(8 \%)\end{array}$ & $\begin{array}{c}\text { Variovorax } \\
(6 \%)\end{array}$ & $\begin{array}{c}\text { Variovorax } \\
(3 \%)\end{array}$ & $\begin{array}{c}\text { Variovo } \\
\operatorname{rax} \\
(11 \%)\end{array}$ & $\begin{array}{c}\text { Variovo } \\
\operatorname{rax} \\
(19 \%)\end{array}$ & $\begin{array}{c}\text { Achrom } \\
\text { obacter } \\
(8 \%)\end{array}$ & \\
\hline & $\begin{array}{c}\text { Duganell } \\
\text { a } \\
(2 \%)\end{array}$ & $\begin{array}{l}\text { Massilia } \\
(2 \%)\end{array}$ & & $\begin{array}{c}\text { Massilia } \\
(3 \%)\end{array}$ & & $\begin{array}{c}\text { Achrom } \\
\text { obacter } \\
(4 \%)\end{array}$ & $\begin{array}{l}\text { Dugan } \\
\text { ella } \\
(6 \%)\end{array}$ & & \\
\hline Class & \multicolumn{9}{|c|}{$\gamma$-Proteobacteria } \\
\hline \multirow{3}{*}{$\begin{array}{l}\text { Gene } \\
\text { ra } \\
(\%)\end{array}$} & & $\begin{array}{c}\text { Pseudomo } \\
\text { nas }(3 \%)\end{array}$ & \multirow[t]{3}{*}{$\begin{array}{l}\text { Lyso } \\
\text { bacte } \\
r \\
(8 \%)\end{array}$} & $\begin{array}{c}\text { Pseudomo } \\
\text { nas }(3 \%)\end{array}$ & $\begin{array}{l}\text { Pseudomo } \\
\text { nas }(3 \%)\end{array}$ & $\begin{array}{l}\text { Unclass } \\
\text { ified } \\
\text { Oxal * } \\
(4 \%)\end{array}$ & $\begin{array}{c}\text { Pseudo } \\
\text { monas } \\
(6 \%)\end{array}$ & $\begin{array}{c}\text { Pseudo } \\
\text { monas } \\
(17 \%)\end{array}$ & $\begin{array}{c}\text { Pseudom } \\
\text { onas } \\
(16 \%)\end{array}$ \\
\hline & & $\begin{array}{c}\text { Pseudoxan } \\
\text { thomonas } \\
(2 \%)\end{array}$ & & $\begin{array}{c}\text { Pseudoxan } \\
\text { thomonas } \\
(6 \%)\end{array}$ & $\begin{array}{c}\text { Pseudoxan } \\
\text { thomonas } \\
(7 \%)\end{array}$ & $\begin{array}{c}\text { Shinella } \\
(4 \%)\end{array}$ & $\begin{array}{l}\text { Lysoba } \\
\text { cter } \\
(6 \%)\end{array}$ & & $\begin{array}{c}\text { Steroidob } \\
\text { acter } \\
(3 \%)\end{array}$ \\
\hline & & & & $\begin{array}{l}\text { Lysobacter } \\
\text { (3\%) }\end{array}$ & & & & & $\begin{array}{c}\text { Stenotrop } \\
\text { homonas } \\
(33 \%)\end{array}$ \\
\hline
\end{tabular}

*NI: non-inoculated plots with mycorrhiza; INOC: inoculated plots with mycorrhiza 


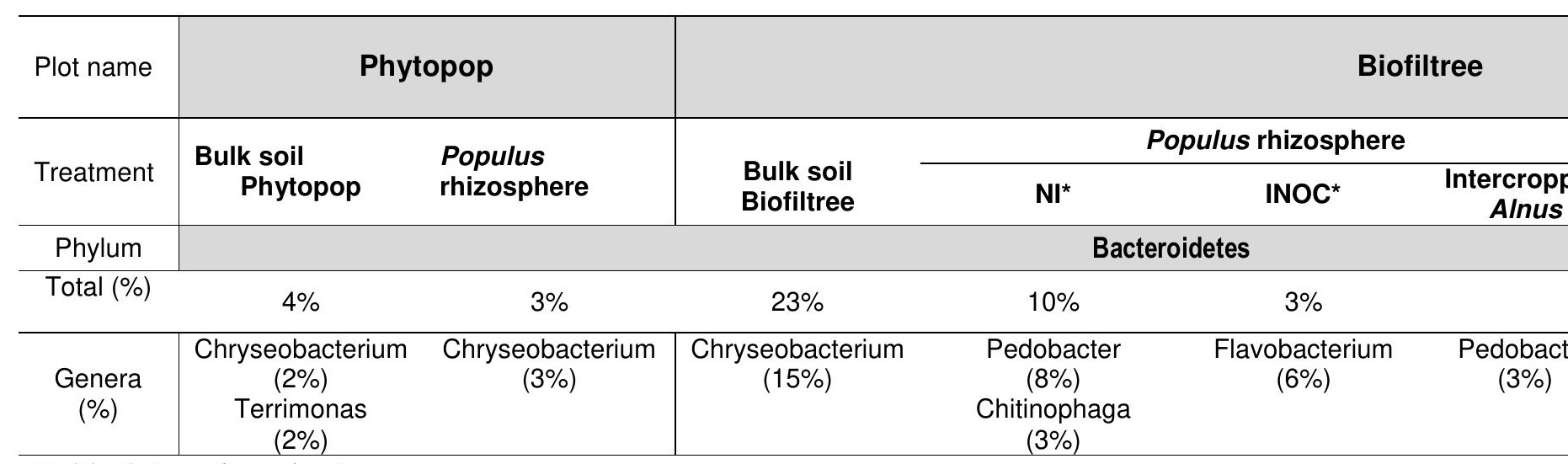

845 Table 2 (continuation)

$846 *$ NI: non-inoculated plots with mycorrhiza; INOC: inoculated plots with mycorrhiza 


\begin{tabular}{|c|c|c|c|c|c|c|c|c|c|c|}
\hline Isolate & $\begin{array}{c}\text { Identification } \\
\text { (16S rDNA) } \\
\text { and ID* }\end{array}$ & Origin & Sider. & Surf. & SoluP & $\begin{array}{l}\mathrm{Cd} \\
0.1 \\
\mathrm{mM}\end{array}$ & $\begin{array}{c}\mathrm{Cu} \\
1 \mathrm{mM}\end{array}$ & $\begin{array}{c}\mathrm{Pb} \\
1 \\
\mathrm{mM}\end{array}$ & $\begin{array}{l}\mathrm{Zn} \\
2.5 \\
\mathrm{mM}\end{array}$ & $\begin{array}{c}\text { IAA } \\
(\mu \mathrm{g} / \mathrm{mL})\end{array}$ \\
\hline SR15 & $\begin{array}{c}\text { Bacillus } \\
\text { MW036883 }\end{array}$ & $\begin{array}{l}\text { Endophyte } \\
\text { poplar }\end{array}$ & + & + & - & - & - & - & + & 6.58 \\
\hline SR18 & $\begin{array}{c}\text { Bacillus } \\
\text { MW036882 }\end{array}$ & $\begin{array}{l}\text { Endophyte } \\
\text { poplar }\end{array}$ & - & + & - & + & - & + & + & 2.52 \\
\hline SR62 & $\begin{array}{c}\text { Sphingomonas } \\
\text { MW036888 }\end{array}$ & $\begin{array}{l}\text { Endophyte } \\
\text { poplar }\end{array}$ & - & - & + & + & - & + & + & 10.8 \\
\hline MR28 & $\begin{array}{l}\text { Rhizobium } \\
\text { MW036864 }\end{array}$ & $\begin{array}{l}\text { Endophyte } \\
\text { maize }\end{array}$ & + & + & + & + & + & + & - & 1.38 \\
\hline MR47 & $\begin{array}{l}\text { Pseudomonas } \\
\text { MW036871 }\end{array}$ & $\begin{array}{l}\text { Endophyte } \\
\text { maize }\end{array}$ & - & + & + & + & - & - & - & 2.89 \\
\hline Sk2.3 & $\begin{array}{c}\text { Bacillus } \\
\text { MW037076 }\end{array}$ & $\begin{array}{l}\text { Rhizosphere } \\
\text { poplar }\end{array}$ & - & + & - & - & - & + & - & 2.07 \\
\hline Sk12.6 & $\begin{array}{l}\text { Rodococcus } \\
\text { MW037075 }\end{array}$ & $\begin{array}{l}\text { Rhizosphere } \\
\text { poplar }\end{array}$ & - & + & + & + & + & + & + & 5.35 \\
\hline Sk20.12 & $\begin{array}{c}\text { Streptomyces } \\
\text { MW037077 }\end{array}$ & $\begin{array}{c}\text { Rhizosphere } \\
\text { Poplar }\end{array}$ & + & - & - & + & - & - & + & 12.13 \\
\hline Sk1.23 & $\begin{array}{c}\text { Bacillus } \\
\text { MW036928 }\end{array}$ & $\begin{array}{l}\text { Rhizosphere } \\
\text { Poplar }\end{array}$ & + & + & - & + & - & - & - & 5.14 \\
\hline Sk11.4 & $\begin{array}{l}\text { Microbacterium } \\
\text { MW037063 }\end{array}$ & $\begin{array}{l}\text { Rhizosphere } \\
\text { poplar }\end{array}$ & + & + & - & + & - & - & - & 0.81 \\
\hline B32.24 & $\begin{array}{c}\text { Bacillus } \\
\text { MW037184 }\end{array}$ & Bulk soil & + & + & - & + & - & + & - & 8.08 \\
\hline
\end{tabular}

Table 3. Bacterial strains isolated from the Pierrelaye field trials and selected for PAHs degradation tests, based on their plant growth promoting traits, surfactant production and metal resistance ability. They were isolated from bulk soil, from the rhizosphere of poplar or maize, or from the endosphere of poplar. 